\title{
Beyond Quotas: Strategies to Promote Gender Equality in Elected Office
}

\author{
Mona Lena Krook \\ Rutgers University
}

\author{
Pippa Norris \\ Harvard University/University of Sydney
}

\begin{abstract}
Gender equality in elected office has become a commitment of national governments and international organizations around the globe. To date, much of the discussion has revolved around electoral gender quotas - policies that set aside seats in political assemblies for women or require that political parties nominate a certain percentage of female candidates. Focusing exclusively on quotas, however, obscures the broader range of efforts around the world to bring more women into political office. This article surveys non-quota strategies used globally, developing an analytic framework for theorizing potential interventions into candidate selection and election processes. Whether used in conjunction with, or as an alternative to, quotas, the diversity of these measures points to a wide array of creative solutions, engaging a variety of actors, which might be pursued to enhance women's political representation. Future research should focus on evaluating the effects of these policies, both alongside and separately from quota policies.
\end{abstract}

Keywords: gender equality policies; electoral quotas; women in politics

Gender parity in elected office has become a central goal of national governments and international organizations around the globe, motivated by arguments that women's inclusion is crucial to achieve justice, promote women's interests and make use of women's resources for the good of society (Phillips, 1995). The roots of this demand extend back to the Universal Declaration of Human Rights, adopted in 1948, which enshrines the equal rights of men and women, including the right to participate in government. A series of other documents signed by United Nations (UN) member states over the years - including the World Plan of Action in Mexico City in 1975, the Convention on the Elimination of All Forms of Discrimination against Women in 1979 and the Nairobi Forward-Looking Strategies in 1985 - resulted in a landmark commitment in the 1995 Beijing Platform for Action, signed by all member states at the UN's Fourth World Conference on Women, to a specific target of 30 per cent women in decision-making positions. ${ }^{1}$

The Platform for Action suggests that this target might only be achieved through greater use of positive action in candidate selection. ${ }^{2}$ Following the conference, electoral gender quotas were passed in more than 100 countries - nearly all specifying 30 per cent women as a minimum proportion of candidates and/or elected officials - in the ensuing years. ${ }^{3}$ As a consequence, both scholars and international organizations have generated a wide body of scientific knowledge on these policies (Dahlerup, 2006; Krook, 2009). Yet the Platform for Action did not solely focus on quotas as a solution. It also highlighted a range of other measures to support gender-balanced decision-making, like 'career planning, tracking, mentoring, coaching, training, and retraining' for women and 'public debate on the new roles of men and women in society and in the family'. ${ }^{4}$

Mention of these strategies in the Platform for Action indicates that quotas alone may not suffice to achieve gender equality in elected office. On the one hand, the application 
of quotas may be enhanced by programs expanding the pool of female candidates, supporting women's legislative capacities and promoting broader transformation in public views towards women in politics (see Franceschet et al., 2012). On the other hand, formal quotas may not be an option in all states and political parties, due to institutional barriers and - perhaps even more importantly - ideological objections to the concept of positive action (Krook et al., 2009). Further, poorly designed policies can prove ineffective in achieving their stated goals (Hoodfar and Tajali, 2011; Jones, 2009). In all these cases, alternative strategies are required to foster greater gender equality.

In contrast to the extensive literature on quotas, however, non-quota measures have not been subject to systematic documentation or research. In addition to being officially documented in legal frameworks and party statutes, quotas exert - in theory - a direct impact on candidate selection and election processes. Non-quota strategies, in contrast, may take a variety of forms, frustrating data collection, and be pursued through both state and civil society channels, more indirectly influencing nomination outcomes. Crucially, these differences suggest that campaigns to increase women's representation need not opt exclusively for one strategy over the other, but that in fact a double-pronged approach may be desirable.

To theorize non-quota strategies in a clearer manner, this article synthesizes work on political recruitment and feminist research on the public/private divide to illuminate potential points of intervention and gendered challenges to change. In so doing, it seeks to go beyond existing typologies placing these measures together with quotas along a spectrum of coercive strength: equality rhetoric, encouraging women to come forward; equality promotion, supporting female candidates through training and funding; and equality guarantees, establishing gender quotas (Lovenduski, 2005). While a useful categorization, these three headings do not exhaust the options available for promoting women in politics and overlook possibilities outside the traditional framework of party politics opportunities that become evident when the analysis takes its starting point from the stages of the political recruitment process.

These insights are used in the first section to conceptualize a range of policy solutions for overcoming women's exclusion. Drawing on diverse primary sources from around the world, the second section presents examples of each type of intervention, organized according to actor categories: civil society, political parties, parliaments and the state. The sheer variety of these measures reveals a wide menu of tactics available for promoting women in politics, while also underscoring the need for a multifaceted approach to tackle the multidimensional and diverse nature of obstacles to women's political inclusion. The article ends with a call for future work to evaluate the advantages and disadvantages of these various strategies, collecting more systematic and rigorous evidence regarding their impact on women's political representation.

\section{Problems and Solutions: A Theoretical Framework}

Devising effective strategies for change requires beginning with an analysis of the status quo, illuminating what must be done in order to set in motion an alternative set of dynamics. Similar to research on gender policy more generally (Bacchi, 1999), however, there are multiple interpretations as to why women are under-represented in political life 
- implying the need for different types of intervention. These views can be reconciled when political recruitment is theorized as a multi-stage process, requiring different elements to advance women. A central issue at each stage is overcoming the public/private divide, which has long justified women's political exclusion.

\section{Models of Political Recruitment}

The political recruitment process is most commonly conceptualized as a sequential model: (1) those eligible to run for office; (2) those who aspire to run for office; (3) those nominated to run for office; (4) those elected to office. If no mechanisms of distortion are at work, the characteristics of individuals at each of these stages should be similar (Norris, 1997). The transition from stage 1 to stage 2 concerns the supply of aspirants, the move from stage 2 to stage 3 reflects the demand for certain types of candidate, and the shift from stage 3 to stage 4 involves the outcomes of elections (Norris and Lovenduski, 1995). In women in politics research, this model has given rise to debates as to whether women's under-representation stems primarily from gender differences in ambition that cause fewer women than men to consider running for political office, biases in the recruitment practices of gatekeepers that lead them to select fewer female candidates than male candidates, or prejudices on the part of voters who prefer to elect men over women (Ashe and Stewart, 2012; Lawless and Fox, 2005; Norris and Lovenduski, 1993).

Scholars favoring supply-side accounts focus on whether potential aspirants feel equipped to run. According to Pippa Norris and Joni Lovenduski (1995), these perceptions are influenced by resources, like time, money and experience, and motivation, such as drive, ambition and interest in politics. Demand-side explanations, in contrast, emphasize assessments of individuals' abilities, qualifications and experience. Because in-depth knowledge of every aspirant is impossible, gatekeepers may rely on 'information short-cuts', using 'background characteristics as a proxy measure of abilities and character' (Norris and Lovenduski, 1995, p. 14). For women, this may lead to direct or imputed negative discrimination - linked at least in part to the descriptive characteristics of elites, who tend to recruit candidates who look like themselves (Kittilson, 2006; Niven, 1998). If the problem is the outcome stage, finally, voters play the crucial role in rejecting female nominees (Black and Erickson, 2003). All three moments are nested within institutional contexts - like electoral systems and gender quotas - shaping actor incentives (Krook, 2009; Norris and Lovenduski, 1995).

\section{The Public/Private Divide}

Recent feminist critiques seek to gender these discussions more explicitly, stressing the gendered dimensions of the 'political market' (Kenny, 2013; Krook, 2010a). Women are a majority of the world's population, but form only a small minority -21.3 per cent - of members of parliament (MPs) worldwide. ${ }^{5}$ This indicates that 'sex', biological differences between women and men, and 'gender', the social meanings given to these differences, introduce important distortions. Gender roles in many societies lead women to have fewer resources of time and money and lower levels of political ambition (Lawless and Fox, 2005; Norris and Lovenduski, 1995). Similarly, selectors may perceive female aspirants as 
less competent or pass them over for selection due to 'out-group' effects or unsubstantiated concerns about voter bias against women.

Gender ideologies are rooted in what feminist theorists term the 'public/private divide'. In most countries, gender norms traditionally prescribe distinct roles in society for the two sexes: men have primary responsibility for affairs in the public sphere, like politics and the economy, while women are assigned a central position in the private sphere, namely the home and the family (Elshtain, 1981). Historically, the public/private divide served as an argument against women's right to vote, on the grounds that this would disturb the balance between the public and private spheres (Pateman, 1994). While it has been muted over time, this divide continues to manifest itself to the present day, albeit to slightly different degrees across cultural contexts. Potential female aspirants may thus confront lingering stereotypes - within themselves, in the eyes of gatekeepers and among citizens - that politics is not a place for women. These challenges may be complicated by expectations that women struggle to balance work and family obligations, strengthening perceptions that they may be less committed and capable politicians.

The result of these dynamics on the supply side is that women may be framed as being less qualified to hold political office. Coming forward as a candidate in the United States, for example, typically privileges male backgrounds and experiences, leading women to be much less likely than men to deem themselves 'qualified' to run for office (Lawless and Fox, 2005). Societal views regarding who should be responsible for household tasks, moreover, may lead marriage and children to be interpreted as a disadvantage for women but as an advantage for men (Norris and Lovenduski, 1995). These challenges may be compounded by what scholars have described as the masculine biases built into existing political institutions and practices (Duerst-Lahti and Kelly, 1995). In many countries, for example, political meetings tend to be held in the evenings, 'reflecting male preferences, schedules, and wifely or maternal supports' (Franceschet, 2005, p. 90).

On the demand side, these perceptions may inform the thinking of gatekeepers selecting candidates. David Niven (1998) finds that male party chairs consistently prefer traits associated stereotypically with men, qualities they recognize in themselves. As a result, men are more likely than women to be encouraged by party elites to run for office (Lawless and Fox, 2005). Interestingly, these patterns may reverse as the proportion of women on party executive committees increases (Kittilson, 2006) and as quotas push elites to consider alternative spheres of recruitment (Krook, 2009). However, doubts linger among some gatekeepers as to the electoral viability of female candidates, which may lead them to promote men despite a wealth of international evidence showing that voters cast votes for women at equal or greater rates than for men (Murray et al., 2012). Gendered norms may thus continue to exert effects on gatekeeper demand, even as women may become more accepted actors in the public sphere.

\section{Policy Interventions}

These concepts and frameworks provide a starting point for theorizing potential points of intervention, as well as the nature of obstacles to women's increased representation. Both are vital for diagnosing the present situation and offering solutions that might help overcome the status quo. The political recruitment model suggests that there are three key 


\section{Figure 1: Intervention Points and Strategies}
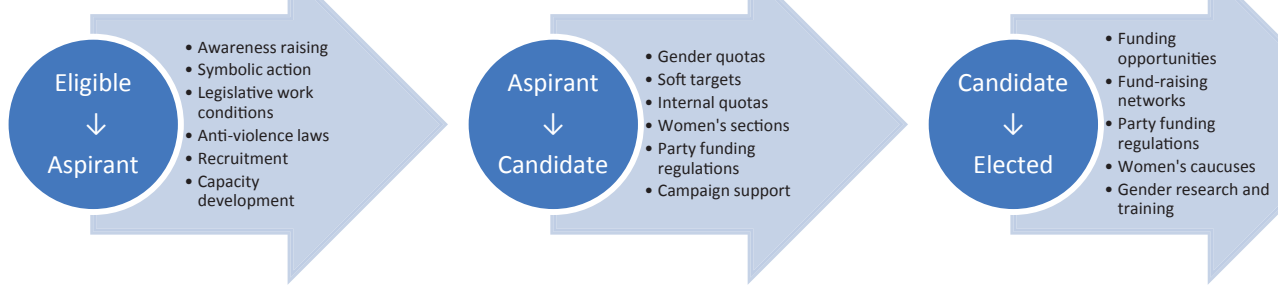

transition moments: from eligible to aspirant, from aspirant to candidate and from candidate to elected official. Although the language of supply and demand suggests that an 'invisible hand' steers outcomes, stages of recruitment can be matched to various interventions, illustrated in Figure 1, permitting the elaboration of strategies as well as comparisons of their goals and projected effects. In contrast to typologies focused exclusively on the strategies of party elites, this discussion highlights that a wide range of actors may play a role in efforts to promote women in politics.

The eligible to aspirant moment requires women believing that they have the qualifications and resources to run for office. A key barrier is overcoming perceptions that women do not belong in politics. One way to do this is through awareness-raising campaigns and monitoring, highlighting the exclusion of women and the ways in which women may contribute to political debates. Civil society actors are well placed to organize such efforts, but these may also benefit from financial and moral support from the state. A related tactic that can be undertaken by parliaments is symbolic action within political institutions, recognizing the roles that women do play in political life. Combined with reforms to legislative working conditions, steps such as these can make politics more 'women friendly' by suggesting that this arena is open to and values women's participation. Finally, state actors might need to intervene with laws to punish violence against women in politics, a phenomenon that can weigh heavily against women's aspirations when their personal security is at risk.

A second obstacle in the move from eligible to aspirant concerns women's interest and self-confidence in pursuing a political career. Civil society organizations and political parties have the most to contribute in this respect. The first task is to identify women who might be excellent candidates, but may thus far have been overlooked by existing political networks. This can be done via various kinds of recruitment and outreach initiatives, assembling lists of names through personal contacts, group mailings or even online suggestion boxes. The next step is to cultivate the skills, knowledge and connections these women might need in order to wage a political campaign, in turn inspiring confidence in their own abilities to stand as candidates. These goals are best served through capacity development programs for women from different ages and backgrounds, which might also include a mentoring component. Together, these various 'transition one' strategies can enhance the supply of female candidates, undermining dynamics of personal socialization and public prejudice to produce a more supportive environment for women to pursue a career in politics. 
Interventions at the aspirant to candidate stage, in contrast, seek to compel gatekeepers most often, party elites - to revise their implicit or explicit biases against potential female candidates. Electoral gender quotas operate primarily at this moment in the recruitment process. In countries with reserved seats, parties have an incentive to put forward female candidates in order to maximize their seat allotment in political assemblies. In the case of quotas applying to the number of candidates, parties have more leeway to comply with quota regulations (Krook, 2009; Murray et al., 2012). An important obstacle, as noted above, is that elites may believe that women are not viable candidates. A number of strategies can help combat this perception. Within the party, soft targets and women's sections can expose male elites to party women and afford women leadership opportunities that are crucial to accumulating political experience. State actors can also play a significant role when parties are reluctant, by using party funding regulations and campaign support opportunities to create incentives or impose sanctions on parties to encourage them to include women. As a group, therefore, these 'transition two' measures address the demand for female candidates, employing both direct and indirect strategies to combat outdated beliefs about women being ineffective or unqualified candidates.

Lastly, the transition from candidate to elected official involves ensuring that women have the resources and support to win. Access to sufficient finance is often critical to success. For individual candidates, special funding opportunities may be available from their own parties. Alternatively, civil society groups may organize fund-raising networks to collect and distribute money to female candidates to increase the success rates of their campaigns. Party funding regulations by the state can also contribute, albeit in a more indirect manner, by tying public financing to the election - and not just the selection - of women. A second way that states can intervene is by imposing placement mandates on quota policies. As the research literature observes, simply nominating more women is no guarantee that greater numbers of women will be elected. What matters is whether women are nominated to 'winnable' districts or positions on party lists (Jones, 2009; Krook, 2009). Once women are elected, parliaments can introduce or support provisions to assist women in being effective legislators, such as women's caucuses and gender-specific research and training. 'Transition three' strategies thus augment the effects of demand-side initiatives, while also reinforcing supply-side programs to empower women politically.

\section{Actors and Aims: Categorizing Non-quota Strategies}

Disaggregating the recruitment process, consequently, opens up a host of different interventions that might be taken to improve gender equality in elected office. To illustrate what these strategies might look like in practice, this section catalogues a wide variety of creative solutions that have been developed globally to overcome the under-representation of women in political life. These initiatives are organized according to the actors primarily engaged in each activity, complementing the framework in the first section by highlighting what different actors can do in more concrete terms to promote women in politics.

\section{Civil Society Actors}

Civil society groups tend to focus most of their efforts on 'transition one' and 'transition three' strategies, a pattern that is not surprising given that these actors cannot themselves 
select candidates. To facilitate the move from eligible to aspirant, civil society groups have engaged in awareness raising and the recruitment and training of potential female candidates. To promote the transition from candidate to elected official, they have developed a variety of fund-raising networks to sustain women's campaigns. Civil society tactics thus focus on more diffuse strategies cultivating cultural transformation, but also provide very practical solutions for enhancing the success of women's political campaigns.

Raising Awareness. One of the most powerful ways that civil society actors can influence gender equality in elected office is by reshaping public attitudes towards women in politics. Changing traditional gender stereotypes can increase the number of women considering a political career, as well as alter how voters and political parties view female candidates. Strategies for combating such stereotypes include media-based campaigns aimed at changing how citizens think about gender and politics, as well as the generation and publication of data and strategies for overcoming women's exclusion.

Media campaigns are quite varied, but share the basic goal of highlighting the current lack of gender balance and the need to elect more women. In the Czech Republic, a poster campaign was sponsored by the group Forum $50 \%$ in the run-up to the 2006 elections. The group placed posters in the Prague subway and street network featuring a long row of ties and the caption: 'Do you really have a choice?' The message implied that while there were some differences among men in politics, there was actually little true 'choice' among candidates - who still were almost exclusively men. Excluding women therefore undermined democracy by restricting the options available to voters. ${ }^{6}$

In Turkey, the Association to Support Women Candidates, KA.DER, has waged similarly innovative campaigns. In preparation for general elections in 2007, for example, the group created posters of well-known businesswomen and female artists wearing a tie or mustache, asking 'Is it necessary to be a man to enter parliament?' In the run-up to local elections in 2009, they used billboards depicting the three male leaders of the main parties shoulder to shoulder, with text implying that the three were united in preferring male candidates over female ones. $^{7}$

Data generation can also be a powerful tool. The data produced by university research centers, ${ }^{8}$ as well as international organizations like the Inter-Parliamentary Union, ${ }^{9}$ have been instrumental in raising awareness about the extent of women's exclusion - as well as where and when major gains have been made. In addition to spurring governments to take action, data disaggregated to the party level can 'name and shame' parties that nominate few women, damaging a party's reputation and possibly its electoral success. In the 2010 elections in Britain, for example, the significantly lower percentage of female MPs elected by the Liberal Democrats, compared with Labour and the Conservatives, was the subject of negative media attention (Evans, 2011).

Recruitment Initiatives. A necessary initial step towards greater gender equality in elected office is to identify and encourage women to run for office, whether in the immediate or distant future. The common thread in these projects is to convince women to consider a political career. Recruitment initiatives organized by civil society organizations are particularly well developed in the US, where the majoritarian electoral system, combined with 
ideological hostility to gender quotas, makes it difficult to achieve dramatic increases in women's political representation, at least overnight.

A recent campaign along these lines is the 2012 Project, a non-partisan campaign initiated by the Center for American Women and Politics at Rutgers University. ${ }^{10}$ The campaign, which included a video titled 'Consider This Your Invitation', ${ }^{11}$ was directed at women aged 45 and older. It targeted women of this age because they were more likely to be at the top of their professions, hold fewer family responsibilities and be financially independent. Women interested in being candidates were connected to leadership institutes, think tanks, training programs and fund-raising networks designed to help them succeed.

Running Start centers its work on a younger demographic, focusing on getting more women engaged in politics and elected to office at a younger age. Running Start's Young Women's Political Leadership Program introduces secondary school girls to the importance of women in leadership and trains them in public speaking, networking, on-camera media training and platform development. The Running Start/Wal-Mart Star Fellowship places seven university-aged women in the offices of female representatives for a semester-long internship, with each Friday spent in a seminar learning the 'nuts and bolts' of political office. ${ }^{12}$ In 2012, the national Girl Scouts organization launched 'To Get Her There', a long-term campaign to create 'balanced leadership' and 'equitable representation of women in leadership positions in all sectors and levels of society in the course of a generation'. ${ }^{13}$

Training Programs. Capacity-building initiatives have developed exponentially since the 1980s, when only a few programs existed worldwide. Such programs are now run by non-partisan networks, university centers and even international organizations. Networks like the 300 Group in the United Kingdom were founded from the realization that women often did not know where to start when pursuing a nomination for office. ${ }^{14}$ In the US, many of these programs are based at universities. ${ }^{15}$ The Rutgers Center for American Women and Politics, for example, runs a number of programs for women who are interested in running for office. The Ready to Run program is divided into two parts, one tailored to women who plan to run in the near future, and one for those who are thinking about running sometime in the future. Additional sessions are targeted towards AfricanAmerican, Hispanic and Asian-American women, to address potential group-specific challenges in the campaign process. ${ }^{16}$

Training events organized by non-university groups come in a variety of forms. Working in nine states, Emerge provides a seven-month program for Democratic women who want to run for elected office. ${ }^{17}$ The White House Project offers interactive leadership development through two- to three-hour online and in-person training sessions, full-day conferences and three-day summits. ${ }^{18}$ More internationally grounded, the Women in Public Service Project (WPSP) seeks to build a new generation of global female leaders. Founded through a partnership between the US Department of State and five leading women's colleges, the WPSP aims to train women to enter the public sector by cultivating the 'strategic leadership skills, energy, and commitment required to tackle today's global challenges'. ${ }^{19}$ 
Fund-Raising Networks. Fund-raising initiatives seek to ensure that women have the financial resources to wage a successful campaign. Perhaps the most well-known initiative is the US-based EMILY's List, a group founded in 1985 which recruits and trains women but, more uniquely, publicizes their names to solicit campaign contributions from supporters across the country. ${ }^{20}$ Recognizing that early campaign money is crucial for establishing the viability of a political campaign, EMILY is an acronym which stands for 'Early Money Is Like Yeast' - because it makes the 'dough' rise. The group claims to have helped elect 87 pro-choice Democratic women members of Congress, 16 senators, 9 governors and over 500 women to state and local office. ${ }^{21}$

Similar fund-raising groups have been established in other countries on the model of EMILY's List, including in Australia, the UK and Italy. Because EMILY's List focuses on electing more women from leftist parties, its success in the US has spurred the establishment of fund-raising groups for women on the political right. WISH List (WISH = Women in the Senate and House) was founded in 1992 to provide strategic advice, training and financial support to pro-choice Republican women running for local, state and national offices all across the country. ${ }^{22}$ The Susan B. Anthony List was created in 1993. It emphasizes the election, education, promotion and mobilization of pro-life women - but with a willingness to support the election of pro-life men over pro-choice women. ${ }^{23}$

\section{Political Party Actors}

Political parties are heavily involved in 'transition two' tactics and, to a more limited extent, 'transition one' and 'transition three' strategies. This pattern accords very closely with their central role in selecting candidates, leading them to be the subject of closer scrutiny in recent years as a potential intervention point for the political empowerment of women (United Nations Development Program and National Democratic Institute, 2011). Reforming their nomination procedures, many socialist and social democratic parties globally have amended their statutes to establish gender quotas (Kittilson, 2006; Krook, 2009). Yet a number of non-quota measures have also been employed by parties of nearly all political persuasions. Women's sections have played a vital role in raising gender equality issues within parties, inspiring women to advance from eligible to aspirant. Aspirant to candidate strategies include setting soft targets, as well as recruiting women and training them to run for office. Parties support women moving from candidate to elected official through additional training and campaign funding initiatives. Party-based tactics therefore have the potential to be very successful - and perhaps the most effective across all actor categories - by getting to the heart of recruitment practices and facilitating connections and resources for women to become party candidates and elected officials.

Women's Sections. Women's sections have traditionally recruited female party members and performed important tasks for the party, including electoral canvassing. Historically, the intention has been more for women to serve the party's interests than for the parties to serve women's interests. Yet over time women's sections in many countries have come to serve as a platform for women inside parties (Lovenduski and Norris, 1993), contributing to policy development, coordinating the activities of female party members, and providing support and training to newly elected female office holders - as well as encouraging more 
general transformation within the party by sensitizing party members, male and female, to the importance of gender equality (United Nations Development Program and National Democratic Institute, 2011, p. 17).

Most parties in Morocco, for instance, have set up women's sections to address women's issues and the needs of female party members; in one party, this has entailed an equality council to ensure women's participation in party decision-making processes. The women's wing of the Sam Rainsy Party in Cambodia has engaged in civic education and voter outreach - and more recently, sought quotas for party leadership positions and provided training for female candidates. Women's sections in Vietnam and Serbia have gone even further by lobbying party leaders to ensure that women were given high positions on electoral lists (United Nations Development Program and National Democratic Institute, 2011).

Soft Targets. Many parties around the globe reject or resist the idea of positive action. In lieu of formal quotas, however, some have introduced regulations that seek to encourage, but do not require, the selection of more female candidates (Krook et al., 2009). These most often appear as informal goals and recommendations. While not intended to bind the hands of elites, these commitments can directly affect women's nomination. In New Zealand, party quotas were proposed by the leader of the NZ Labour Party following the adoption of a new electoral law in 1993. This idea was rejected in favor of changing the party constitution to include a principle of 'gender balance' for all selection procedures. At each selection conference, the party is thus supposed to 'pause for thought' after each bloc of five candidates to consider the balance of gender, ethnicity, age and experience (Catt, 2003).

Recruitment Initiatives. Women's sections and party leaders have also devised new ways of recruiting women to stand as candidates. Prior to the adoption of formal quotas in Sweden, women's sections inside the major parties assembled databases containing the names and curricula vitae of potential female candidates, which could be presented to party officials as they sought to find women to put on their lists (Wistrand, 1981). While women's sections may have more contacts with women inside and outside the party, such a task need not be restricted to their organization. A local party leader in Sweden, for example, used the list of female party members in his district to contact women personally, one by one, to ask them to consider putting themselves forward as candidates. ${ }^{24}$

Capacity Building. Programs can be offered to women currently running for office, as well as to those who might consider doing so in the future, focusing on topics like fostering motivation, improving public speaking and demystifying the campaign process. While this strategy is most commonly pursued by civil society actors, one party-based initiative is Women2Win in the British Conservative Party. The group seeks to promote 'the brightest and best women the party has to offer' through support, advice and training in public speaking and media skills. It also hosts networking events for women at all levels of politics. A parallel goal is convincing grassroots associations of 'the benefits of putting their trust in female candidates'. ${ }^{25}$

In El Salvador, the Frente Farabundo Martí para la Liberación Nacional sends money from the party budget to the National Ministry for Women, which uses it for national 
assemblies, training events, and consultations with party women (Sidhu and Meena, 2007, p. 20). Other efforts focus more explicitly on transforming female candidates into elected officials. In Australia, the Labor Party established a mentoring program pairing first-time candidates with more experienced politicians (United Nations Development Program and National Democratic Institute, 2011, p. 33), while the Mexican National Action Party (PAN) runs seminars, workshops, fora and courses for women to level the political playing field (Llanos and Sample, 2009).

Campaign Funding. Financial support can help overcome perceptions that women are not viable candidates, as well as compensate for the fact that women often lack access to the formal and informal networks that supply campaign funds. Women may also have expenses not incurred by men, for example to help with household tasks, childcare or extra security (Sidhu and Meena, 2007, pp. 10-1). One approach is to create a special internal party fund for women's campaigns, while another is to provide subsidies of one kind or another to female candidates.

A party fund within the Liberal Party in Canada assists women with campaign costs. The money is raised through fund-raising events, direct mailings and the internet, and the party maintains centralized control in determining who is prioritized in receiving contributions. Female candidates can be reimbursed up to $C \$ 500$ for childcare expenses incurred when seeking a nomination, $C \$ 500$ for travel when campaigning in geographically large constituencies, and a further $\mathrm{C} \$ 500$ when pursuing a nomination in districts where an incumbent is retiring (United Nations Development Program and National Democratic Institute, 2011, p. 28). These provisions recognize that women often assume primary parenting responsibilities, while also seeking to encourage them to contest 'winnable' districts.

Party subsidies are somewhat rare, but typically seek to overcome one of the major financial barriers to women's participation, especially in developing countries: the need to pay a deposit to register a candidacy. In Sierra Leone, several parties - including the main opposition party - have reduced or waived nomination fees for women. ${ }^{26}$ Similarly, the ruling People's Democratic Party in Nigeria introduced a waiver of the mandatory registration fees for women aspiring to any elective post on the party label. ${ }^{27}$ In Cambodia, the Sam Rainsy Party assists women with membership dues and candidate nomination fees, and to enhance their electoral success provides female candidates with basic items, like clothes and a bicycle to use while campaigning (United Nations Development Program and National Democratic Institute, 2011, p. 28).

\section{Parliamentary Actors}

Legislatures can shape gender equality in elected office at 'transition one' and 'transition three' moments. The power of the public/private division has led to a lingering sense among women that they are outsiders to the male world of politics. As such, many view parliament as a 'gentlemen's club', with a plethora of unwritten rules and codes of conduct, on one hand, and disparaging or condescending sexist remarks, on the other (Palmieri, 2011, p. 84; compare Duerst-Lahti and Kelly, 1995). Legislatures can thus shape eligibleto-aspirant decisions by signaling that political institutions are open to women and making 
politics a more attractive career for women. Once women have moved from candidate to elected official, parliaments can enhance their capacities in a male-dominated environment by providing resources to help them be more effective legislators. Parliamentary strategies, consequently, include more indirect work to enact cultural change, seeking to erode the exclusive association between men and the public sphere, which may or may not have immediate effects. They can also have a direct impact in retaining the women who are elected by creating a more desirable and successful work environment.

Language. Parliaments worldwide are saturated with practices and images that can reinforce as well as challenge social hierarchies. ${ }^{28}$ For actors inside institutions - as well as visitors to them - these images can implicitly suggest which actors can participate and which cannot. In addition to rules regarding sex-neutral language in bills, a recent discussion has revolved around the convention in some languages to use the male plural form when addressing a mixed group. Following criticisms that the term 'señores diputados' in effect rendered women invisible within the institution, Spanish legislators revised the parliamentary standing orders to mandate that both masculine and feminine forms be used in plenary and committee debates. ${ }^{29}$ They also decided to issue all future constitutional amendments in the name of 'Congress', a more gender-neutral term than 'Congress of Deputies' employing the masculine plural form (Palmieri, 2011, p. 86).

Images. Other steps taken on a symbolic plane to signal openness to women's participation include the revision of parliamentary information materials. Certain legislatures, for instance, provide a separate list of female members, drawing attention to the fact that women serve in parliament. ${ }^{30}$ Some websites also showcase events taking place related to gender equality, like anniversary celebrations of women's right to vote and the passage of women-friendly legislation (Palmieri, 2011). In France, a special section was added to draw attention to the history of women in politics, ${ }^{31}$ including an extensive set of videos and other links on women's role in French politics. ${ }^{32}$

Other legislatures have organized temporary or permanent exhibitions to showcase the role of women in politics. Following a five-party motion in Sweden in 1989, pointing out that nearly all portraits in the parliament building were of men, a 'women's room' was installed in a hallway often passed by MPs when going from the chamber to committee rooms, as well as by both Swedish and foreign visitors. At first, the room featured pieces of artwork by female artists depicting women's lives. In 2005, however, a proposal was made to inspire visitors with portrayals of 'strong, brave, successful Swedish women'. ${ }^{33}$ The current exhibition includes political pioneers and role models from different parties, including the first female MP, first female party leader and first female speaker.

Working Conditions. According to a global survey of MPs, many women perceive the traditional working practices of parliaments to be problematic (Ballington, 2008), highlighting 'work-life balance' issues as the greatest challenge when serving in parliament (Palmieri, 2011, p. 97). One set of issues concerns the timing of sittings. Many chambers work late into the night, precluding MPs from being at home with their families. Recognizing that this was a problem for all members, but especially for women as societal expectations often placed a greater burden on them for such tasks, several legislatures have 
established new rules regarding hours. In Denmark, no votes may take place after 7 p.m., while in Sweden evening votes are avoided as much as possible. Additionally, voting is generally not done on Mondays or Fridays. Another family-friendly provision involves aligning the parliamentary schedule with the school calendar, now done in nearly 40 per cent of parliaments (Palmieri, 2011, p. 92).

A related set of issues concerns parental leave. This problem came to a head several years ago in Colombia, where a proposed bill stipulated that legislators would lose their seats if they did not attend a certain number of sessions - a law that was intended to curb absenteeism, but one that also had particular implications for pregnant women (and was later defeated on these grounds). Voting can also be an issue in cases of parental leave. In parliaments with substitute members, this problem can be more easily resolved with alternates. In Australia, Armenia and France, members are not replaced, as their office is not considered vacant. A special provision for nursing mothers was introduced in Australia in 2008, enabling them to cast a proxy vote (Palmieri, 2011, p. 95).

Debates over childcare and breastfeeding have become more common in recent years, with the election of greater numbers of younger women. The response has been uneven. In Germany, childcare centers cater to staff, but not members, while in Sweden all MPs are entitled to use the center. In Scotland, childcare facilities are available to members and visitors, viewed as 'an important part of creating an open and accessible Parliament'. ${ }^{34}$ In a similar vein, new challenges to parliamentary rules - prohibiting food and 'visitors' on the chamber floor or in committee rooms - surfaced in the late 1990s in Australia and the United Kingdom, when a string of new female members needed to breastfeed their babies. ${ }^{35}$ In some countries, like Peru, a solution has been to set up a room for this purpose within the parliament building itself (Palmieri, 2011, p. 95).

Research and Capacity Building. Targeting the third transition, from candidate to elected official, some legislatures have devised new ways to support women in parliament once they are elected, both individually and as a group. While many legislatures globally offer induction sessions for newly elected members, resources for translating this knowledge into practice may be incomplete - especially for those who may be outside 'old boys' networks. To combat this problem, a Research Center for Women's Advancement and Gender Equality was established in Mexico in 2005 to provide specialized technical support and analytical information services. While the center works with both men and women, with the aim of promoting gender equality policy, ${ }^{36}$ in practice it works largely with female deputies to craft bills. The demand for such services is clear: in the first two terms of its existence, the center provided 428 information services to MPs, including 65 reports on legislation, 35 research papers and 49 analyses (Palmieri, 2011, p. 55). A similar center, the Technical Unit on Gender Equality and Equity, was created in Costa Rica in 2009 to provide gender training to staff, provide expert advice and coordinate with civil society. ${ }^{37}$

Women's Caucuses. Women's caucuses can be especially crucial in supporting women's legislative work, bringing women together across partisan lines and serving as a means to connect with actors in civil society (Archenti and Johnson, 2006). They can range from more formal organizations, with permanent offices and objectives, to more informal groups, with meetings convened as necessary, to non-formal gatherings, like monthly 
breakfast meetings. Their funding can derive from voluntary fees, as in Pakistan, all the way to international sources, as in Peru (Palmieri, 2011, p. 48). The degree of formality and cooperation often depends on the strength of party politics, with women being less likely to come together formally where partisan divides are strong.

One particularly comprehensive model is the Forum of Rwandan Women Parliamentarians, established during the transitional assembly in 1996. All female members in both houses of parliament are included. Formally recognized, with its own office, the Forum engages in advocacy on behalf of women, identifying legislative priorities and reviewing legislation to ensure that it is gender sensitive. To this end, the caucus coordinates with the Gender and Family Promotion Committee inside parliament, as well as with women's groups in civil society (Palmieri, 2011, p. 46). At the same time, it seeks to build up the capacity of members through training workshops, administrative assistance and expert technical advice. ${ }^{38}$

\section{State Actors}

State actors, finally, engage primarily in interventions at the 'transition two' and 'transition three' stages, seeking to influence how parties approach the nomination and capacity building of female candidates. The state can address aspirant-to-candidate dynamics by encouraging parties to select more women through positive and negative incentives linked to party funding regulations and publicly provided campaign support. Actors at this level can also enhance the likelihood that female candidates will be elected through regulations tying public finance to women's election, not just their nomination, and by implementing new laws to combat violence against female politicians. These various strategies can, in turn, shape the prospects for 'transition one', if women are as a result more willing to run for office due to increased resources and security for their campaigns. State-based initiatives can thus provide strong motivations for parties to alter their recruitment and selection practices, while reducing disincentives for women to run.

Party Funding. In countries where parties are publicly funded, regulating how these funds are used can be an effective way of promoting women's participation (Childs, 2013). ${ }^{39}$ Candidate-centered regulations present incentives for parties to nominate or elect greater numbers of women, with funding being conditioned on how many women are put forward by a given party. In some cases, these requirements are tied explicitly to quota provisions, with parties losing a share of funding if they do not nominate a certain percentage of female candidates, as in France where state subsidies are reduced by 75 per cent of the difference between the proportions of women and men if these exceed more than 2 percentage points, and in Ireland, where party funding is reduced by 50 per cent if parties do not nominate at least 30 per cent women. ${ }^{40}$

In other countries, parties are rewarded for promoting women, but the regulation provides encouragement; it does not per se require that parties nominate or elect female candidates. In Ethiopia, a percentage is not specified, but support is determined according to how many women are nominated by each party. In Georgia, the reward is more explicitly enumerated: a party will receive an additional 10 per cent of the funds it is entitled to if there are at least 20 per cent candidates of a different sex per group of ten 
candidates. In states as diverse as Bolivia, Bosnia-Herzegovina, Colombia, Mali and Niger - only some of which have quotas - between 5 and 10 per cent of state funding is allocated to parties based on their share of women elected, thereby encouraging parties to elect as many women as possible. In Papua New Guinea, parties must not simply endorse a female candidate, but must have spent an amount of expenses on her campaign.

In other countries, the regulation is more explicitly formulated as a bonus. In ascending order, political parties are entitled to a bonus of 10 per cent of the amount allocated for each elected member of the under-represented sex in Croatia; a 50 per cent increase in public funding if 30 per cent of elected officials are women in Burkina Faso (United Nations Development Program and National Democratic Institute, 2011, p. 29); and a doubling of funding if a party nominates at least 30 per cent women and succeeds in electing at least 20 per cent women in Haiti. In Togo, a unique case, the nomination fee that parties must pay to contest elections is reduced by 25 per cent if the party list contains female candidates.

Capacity-building regulations provide a more indirect route towards gender equality in elected office. Rather than seeking to influence nomination processes, these laws require that parties earmark a certain percentage of their public funding for activities contributing to the political development of women. In Colombia and Ireland, requirements are vague: parties must simply spend some amount of their funding to promote the inclusion and participation of women. In Brazil, Italy and South Korea, an amount is identified between 5 and 10 per cent of state subsidies - but activities are not, referring only to those promoting the participation of women.

Other laws, however, do stipulate how funds must be used. Each party in Mexico, for instance, must devote 2 per cent of its annual public funding to the training, promotion and development of women's leadership skills. In Panama, at least 10 per cent of the 25 per cent of party funding dedicated to civic and political education activities must be channeled solely towards the training of women. In Finland, all parliamentary parties must use 12 per cent of their annual party subsidy to fund a women's wing, and in Honduras parties are assessed a fine of 5 per cent of their public funding if they do not develop and provide proof of a non-discrimination policy.

Campaign Support. In a global survey of 300 MPs, lack of finances emerged as one of the most significant factors deterring women from entering politics (Ballington, 2008, p. 18). One way that state agencies can compensate for gender differences in financial support is through indirect funding of political campaigns. In Timor Leste, more broadcast media time is given to parties that place women in high positions on their party lists, which in past elections has had the effect of encouraging the nomination of women and their visibility during the campaign (Sidhu and Meena, 2007, p. 31; United Nations Development Program and National Democratic Institute, 2011, p. 30). In Afghanistan, the state-run media are required to provide equal facilities to all candidates, including broadcasting and advertising messages free of cost. ${ }^{41}$ While it was gender neutral in its formulation, a higher proportion of female candidates (76 per cent) took advantage of this opportunity in 2005 than did male candidates (55 per cent). In Nigeria, the federal government launched the Nigerian Women's Trust Fund in 2011. Acting through the Ministry of Women Affairs 
and Development, the aim is to provide aspiring female politicians with financial and other resources, regardless of political affiliation. ${ }^{42}$

Anti-violence Laws. An emerging problem in some countries is electoral violence against women running for and/or holding elected office. It includes inflicting physical, sexual or psychological harm or suffering, with the intention of deterring women's political participation. Importantly, such violence can occur in public or private life: within political parties, across political parties, at the level of the state, as well as within a woman's own family (SAP International, 2010, p. 27). Acknowledging this problem, legislators in several Latin American countries, including Bolivia, Ecuador, Guatemala and Mexico, have sought laws to prevent and punish all forms of persecution, harassment and violence against women in politics (Salguero Carrillo, 2009). In 2012, Bolivian legislators approved the ground-breaking Law against Harassment and Political Violence against Women. Passage came in response to demands from women's organizations which pointed out that, over the previous eight years, police had received more than 4,000 complaints of harassment from women participating in politics - a figure that most likely does not reflect the full extent of the problem, given that many incidents are not reported. ${ }^{43}$

\section{Conclusions: Electoral Quotas and Beyond}

Contemporary efforts to promote gender equality in elected office have largely revolved around gender quotas. While these policies constitute a crucial mechanism for jumpstarting progress, they do not exhaust the list of options available for recasting the political recruitment process to motivate more women to consider a political career, encourage political parties to select more female candidates, or enhance women's prospects of electoral success. This article seeks to broaden the conversation by collecting together and categorizing the range of non-quota strategies that might be employed at various stages of this process. The diversity of measures uncovered - implemented by civil society groups, political parties, parliaments and state agencies - reveals a broad array of creative solutions that might be pursued.

Exploring options beyond quotas is vital for all countries. In states with quotas, additional strategies may serve as an important complement, expanding the pool of potential candidates and promoting a broader transformation in public views towards women in politics. In countries where quotas are unlikely to reach the agenda, or where quotas have been rejected or overturned, non-quota strategies present a crucial alternative path to women's political integration. Evidence from around the world suggests that the main barriers to women's increased election are political, rather than social, economic or cultural (Kittilson, 2006; Krook, 2010b). Dramatic changes are thus not likely to occur without deliberate interventions to increase the number of viable female candidates, whether this is through quotas or through non-quota initiatives to empower women in politics.

The crucial next step for scholars and activists is to investigate the relative effectiveness of these strategies. Both single-country and comparative research is needed, to determine whether particular interventions have a greater impact than others - and under what institutional and cultural conditions. More systematic assessments are necessary to make use of scarce resources and design the most effective strategies for a given case. Capacity- 
building programs, in particular, are often preferred over other strategies. These may not be the best use of time and money, however, if few women ever get elected; other initiatives may be needed to ensure that women are being selected and promoted as candidates at later stages. At the same time, some lessons may not translate across countries: candidate fund-raising, popular in the US, may prove largely irrelevant in European systems with state-funded party campaigns, just as public funding regulations are of little use in countries without state subsidies. A new generation of studies - including those comparing quota and non-quota strategies in individual countries - is therefore essential to ascertain which strategies may go the furthest in different contexts to achieve greater gender balance in politics.

(Accepted: 28 September 2013)

(Published online: 14 January 2014)

\section{About the Authors}

Mona Lena Krook is Associate Professor of Political Science at Rutgers University. She is the author of Quotas for Women in Politics: Gender and Candidate Selection Reform Worldwide (Oxford University Press, 2009) and co-editor of The Impact of Gender Quotas (Oxford University Press, 2012). Her current research, funded by a Faculty Early Career Development (CAREER) Award from the National Science Foundation, explores the effects of electoral gender quotas 'beyond numbers' in Western Europe, Latin America and sub-Saharan Africa. Mona Lena Krook, Department of Political Science, Rutgers University, 89 George Street, New Brunswick, NJ 08901, USA; email: m.l.krook@rutgers.edu

Pippa Norris is the McGuire Lecturer in Comparative Politics at the John F. Kennedy School of Government, Harvard University; Laureate Fellow and Professor of Government and International Relations at the University of Sydney; and Director of the Electoral Integrity Project. She has also directed the Democratic Governance Group at UNDP and won the Johan Skytte award. Among more than 40 books, her latest is Why Electoral Integrity Matters (Cambridge University Press, 2014). Pippa Norris, John F. Kennedy School of Government, Harvard University, 110 Littauer Building, 79 JKF Street, Cambridge, MA 02138, USA; and Department of Government and International Relations, University of Sydney, 259 Merewether Building, Sydney, NSW 2006, Australia; email: pippa_norris@ harvard.edu

\section{Notes}

The authors would like to thank Arielle Rothstein for her research assistance, as well as the editors and anonymous reviewers at Political Studies for their detailed comments and suggestions for improving the manuscript.

1 Para. 182, http://www.un.org/womenwatch/daw/beijing/fwcwn.html

2 Paras 184, 189, 192, 194, http://www.un.org/womenwatch/daw/beijing/fwcwn.html

3 For an updated list, see http://www.quotaproject.org

4 Para. 194, http://www.un.org/womenwatch/daw/beijing/fwcwn.html

5 http://www.ipu.org/wmn-e/world.htm

6 http://www.5050democracy.eu/

7 http://www.ka-der.org.tr/

8 See, for example, http://www.cawp.rutgers.edu/fast_facts/index.php

9 http://www.ipu.org/wmn-e/classif.htm and http://www.ipu.org/wmn-e/classif-arc.htm

10 http://www.cawp.rutgers.edu/education_training/2012Project/index.php

11 http://www.youtube.com/watch?v=4Mn601QUwP0

12 http://www.runningstartonline.org/

13 http://www.examiner.com/article/girls-scouts-of-america-launches-to-get-her-there-on-100th-anniversary

14 Personal interview with Lesley Abdela, founder of the 300 Group.

15 For a state-by-state list, see: http://www.cawp.rutgers.edu/education_training/trainingresources/index.php

$16 \mathrm{http}: / /$ www.cawp.rutgers.edu/education_training/ReadytoRun/Diversity_Initiative.php

17 http://www.emergeamerica.org/

$18 \mathrm{http} / / /$ thewhitehouseproject.org/

$19 \mathrm{http}: / /$ womeninpublicservice.org/

20 http://www.emilyslist.org

21 http://emilyslist.org/who/we_are_emily/

22 http://www.thewishlist.org/ 
23 http://www.sba-list.org/

24 Based on research by Jessika Wide.

25 http://www.women2win.com

26 http://www.ndi.org/node/14065

27 Nigeria Report to the UN CEDAW Committee, April 2003, 19.

28 http://www.2.warwick.ac.uk/fac/soc/pais/research/gcrp/

29 Similar steps have been taken in some Latin American parliaments. See, for example, the website of the Mexican Chamber of Deputies, referring to 'Diputadas y Diputados': http://www.diputados.gob.mx/inicio.htm

30 http://www.aph.gov.au/About_Parliament/Parliamentary_Departments/Parliamentary_Library/Parliamentary_Handbook/ womennow; http://www.parliament.uk/mps-lords-and-offices/mps/; http://www.assemblee-nationale.fr/histoire/femmes/ index.asp

31 http://www.assemblee-nationale.fr/histoire/femmes/citoyennete_politique.asp

32 http://www.assemblee-nationale.fr/histoire/femmes/citoyennete_politique_PARITE.asp

33 http://www.riksdagen.se/sv/Dokument-Lagar/Forslag/Motioner/Riksdagens-kvinnorum_GT02K239/?text=true

34 http://www.scottish.parliament.uk/visitandlearn/12522.aspx

35 http://www.economist.com/node/303977

36 http://www.3.diputados.gob.mx/index.php/camara/001_diputados/006_centros_de_estudio/05_centro_de_estudios_para_el_ adelanto_de_las_mujeres_y_la_equidad_de_genero/000d_que_hacemos

37 http://www.asamblea.go.cr/Centro_de_informacion/Unidad_Tecnica_Igualdad/default.aspx

$38 \mathrm{http}: / / \mathrm{www} . \mathrm{rwandaparliament.gov.rw/parliament/forumrwpf.aspx}$

39 All data are from http://www.idea.int/political-finance/, unless specified in the text.

40 http://www.irishtimes.com/newspaper/ireland/2012/0720/1224320450882.html

$41 \mathrm{http}: / /$ aceproject.org/epic-en/CDCountry?set_language=en\&topic=ME\&country=AF

42 http://ngonewsafrica.org/archives/3802

43 http://www.unwomen.org/2012/06/bolivia-approves-a-landmark-law-against-harassment-of-women-political-leaders/

\section{References}

Archenti, N. and Johnson, N. (2006) 'Engendering the Legislative Agenda with and without the Quota', Sociología, Problemas e Prácticas, 52, 133-53.

Ashe, J. and Stewart, K. (2012) 'Legislative Recruitment: Using Diagnostic Testing to Explain Underrepresentation', Party Politics, 18 (5), 687-707.

Bacchi, C. L. (1999) Women, Policy, and Politics. Thousand Oaks CA: Sage.

Ballington, J. (2008) Equality in Politics. Geneva: Inter-Parliamentary Union.

Black, J. H. and Erickson, L. (2003) 'Women Candidates and Voter Bias', Electoral Studies, 22 (1), 81-100.

Catt, H. (2003) 'Frail Success? The New Zealand Experience of Electing Women'. Paper presented at the ECPR Joint Sessions of Workshops, Edinburgh, Scotland, 28 March-2 April.

Childs, S. (2013) 'In the Absence of Quotas: Regulating Political Parties for Women's Representation'. Paper presented at the European Conference on Politics and Gender, Barcelona, Spain, 21-23 March.

Dahlerup, D. (ed.) (2006) Women, Quotas, and Politics. London: Routledge.

Duerst-Lahti, G. and Kelly, R. M. (eds) (1995) Gender Power, Leadership, and Governance. Ann Arbor MI: University of Michigan Press.

Elshtain, J. B. (1981) Public Man, Private Woman. Princeton NJ: Princeton University Press.

Evans, E. (2011) Women and the Liberal Democrats. Manchester: Manchester University Press.

Franceschet, S. (2005) Women and Politics in Chile. Boulder CO: Lynne Rienner.

Franceschet, S., Krook, M. L. and Piscopo, J. M. (eds) (2012) The Impact of Gender Quotas. New York: Oxford University Press.

Hoodfar, H. and Tajali, M. (2011) Electoral Politics: Making Quotas Work for Women. London: Women Living under Muslim Laws.

Jones, M. P. (2009) 'Gender Quotas, Electoral Laws, and the Election of Women', Comparative Political Studies, 42 (1), 56-81.

Kenny, M. (2013) Gender and Political Recruitment. New York: Palgrave.

Kittilson, M. C. (2006) Challenging Parties, Changing Parliaments. Columbus OH: Ohio State University Press.

Krook, M. L. (2009) Quotas for Women in Politics. New York: Oxford University Press.

Krook, M. L. (2010a) 'Beyond Supply and Demand: A Feminist-Institutionalist Theory of Candidate Selection', Political Research Quarterly, 63 (4), 707-20.

Krook, M. L. (2010b) 'Studying Political Representation', Perspectives on Politics, 8 (1), 233-40.

Krook, M. L., Lovenduski, J. and Squires, J. (2009) 'Gender Quotas and Models of Political Citizenship', British Journal of Political Science, 39 (4), 781-803.

Lawless, J. and Fox, R. L. (2005) It Takes a Candidate. New York: Cambridge University Press.

Llanos, B. and Sample, K. (2009) 'From Words to Action: Best Practices for Women's Participation in Latin American Political Parties'. Available from: http://www.idea.int/publications/from_rhetoric_to_practice/en.cfm [Accessed 28 December 2012].

Lovenduski, J. (2005) Feminizing Politics. Cambridge: Polity Press.

Lovenduski, J. and Norris, P. (eds) (1993) Gender and Party Politics. London: Sage. 
Murray, R., Krook, M. L. and Opello, K. A. R. (2012) 'Why are Gender Quotas Adopted?', Political Research Quarterly, 65 (3), 529-43.

Niven, D. (1998) 'Party Elites and Women Candidates', Women and Politics, 19 (2), 57-80.

Norris, P. (1997) Passages to Power: Legislative Recruitment in Advanced Democracies. New York: Cambridge University Press.

Norris, P. and Lovenduski, J. (1993) 'Supply-Side Explanations of Candidate Selection in Britain', British Journal of Political Science, 23 (3), 373-408.

Norris, P. and Lovenduski, J. (1995) Political Recruitment: Gender, Race and Class in the British Parliament. New York: Cambridge University Press.

Palmieri, S. (2011) Gender-Sensitive Parliaments. Geneva: Inter-Parliamentary Union.

Pateman, C. (1994) 'Three Questions about Womanhood Suffrage', in C. Daley and M. Nolan (eds), Suffrage and Beyond. New York: New York University Press, pp. 331-48.

Phillips, A. (1995) The Politics of Presence. New York: Oxford University Press.

Salguero Carrillo, E. (2009) 'Political Violence against Women', The World of Parliaments: A Review, 36. Available from: http://www.ipu.org/news-e/wop/36/4.htm [Accessed 9 September, 2012].

SAP International (2010) Violence against Women in Politics. Lalitpur: South Asia Partnership International.

Sidhu, G. L. and Meena, R. (2007) Electoral Financing to Advance Women's Political Participation. New York: United Nations Development Program.

United Nations Development Program and National Democratic Institute (2011) Empowering Women for Stronger Political Parties. New York: United Nations Development Program and National Democratic Institute.

Wistrand, B. (1981) Swedish Women on the Move. Stockholm: Swedish Institute. 